\title{
Consequences of the association between HTLV-1 and tuberculosis
}

\author{
Maria de Lourdes Santana Bastos ${ }^{1 *}$, Yuri Neves ${ }^{1}$, Natália Carvalho', Anselmo Souza', Abraão Neto', \\ Isadora Siqueira², Silvane Santos ${ }^{1}$, Edgar M Carvalho ${ }^{1,2}$ \\ From 17th International Conference on Human Retroviruses: HTLV and Related Viruses \\ Trois Ilets, Martinique. 18-21 June 2015
}

HTLV-1 modifies the immune response and clinical presentation of bacterial, fungal and helminthic infections. There are also evidences that helminthic infections may modify disease expression related to HTLV-1, increasing the occurrence of Adult $\mathrm{T}$ cell leukemia (ATL) and decreasing the development of HTLV-1 associated myelopathy or tropical spastic paraparesis (HAM/ TSP). Recently it has been shown that HTLV-1 increases susceptibility for tuberculosis (TB) but the consequences of this co-infection in the clinical course of TB and HTLV-1 infection is not so clear. The aim of this study was to evaluate if TB influences neurologic disease in HTLV-1 infected subjects and to evaluate sequels of TB in HTLV-1 infected individuals. This is a nested case control study with the participation of 32 patients with previous diagnosis of $\mathrm{TB}$ and positivity sorology for HTLV-1 and 32 controls with HTLV-1 without TB paired by age, gender and time of admission in the clinic. Of the 32 patients with TB 29 had pulmonary $\mathrm{TB}$, one had pleural $\mathrm{TB}$, one laryngeal $\mathrm{TB}$ and the other lymphonode TB. Only $2(6,2 \%)$ developed a second episode of TB. Among those who have been treated for TB 8 (25\%) patients complained of dyspnea, 3 without evidence of pulmonary disease, 3 cases had chronic obstructive pulmonary disease (COPD) and two cases had bronchial overactivity. Regarding HTLV-1 associated disease probable HAM/TSP was diagnosed in $4(12,5 \%)$ of the TB patients and in $6(18,7 \%)$ of the patients who only have HTLV-1 infection $(\mathrm{P}>0.05)$. Definitive HAM/TSP was diagnosed in $10(31,2 \%)$ of the co-infected patients with HTLV-1 and TB and in 4 $(12,5 \%)$ in the group who only had HTLV-1 $(\mathrm{P}<0.05)$. While HTLV-1 appears to not influence the severity of

Serviço de Imunologia - Hospital Universitário Professor Edgard Santos, Salvador, Bahia, Brazil

Full list of author information is available at the end of the article
Micobacterium tuberculosis infection TB was highly associated with HAM/TSP.

\section{Authors' details}

${ }^{1}$ Serviço de Imunologia - Hospital Universitário Professor Edgard Santos, Salvador, Bahia, Brazil. ${ }^{2}$ Centro de Pesquisa Gonçalo Muniz - FIOCRUZ, Salvador, Bahia, Brazil.

Published: 28 August 2015

\section{doi:10.1186/1742-4690-12-S1-P77}

Cite this article as: de Lourdes Santana Bastos et al: Consequences of the association between HTLV-1 and tuberculosis. Retrovirology 2015 12(Suppl 1):P77.
Submit your next manuscript to BioMed Central and take full advantage of:

- Convenient online submission

- Thorough peer review

- No space constraints or color figure charges

- Immediate publication on acceptance

- Inclusion in PubMed, CAS, Scopus and Google Scholar

- Research which is freely available for redistribution
() Biomed Central 